\title{
Post caesarean scar endometriosis: reporting three cases
}

\section{Ruchi Thakur*, Pradip W. Sambarey, Desai Katha}

Department of Obstetrics and Gynecology, B. J. Government Medical College and Sassoon General Hospitals, Pune, Maharashtra, India

Received: 05 January 2017

Revised: 04 February 2017

Accepted: 06 February 2017

\section{*Correspondence:}

Dr. Ruchi Thakur,

E-mail: ruchishankar@hotmail.com

Copyright: (C) the author(s), publisher and licensee Medip Academy. This is an open-access article distributed under the terms of the Creative Commons Attribution Non-Commercial License, which permits unrestricted non-commercial use, distribution, and reproduction in any medium, provided the original work is properly cited.

\section{ABSTRACT}

Scar endometriosis remains under diagnosed entity. A high index of suspicion is required for correct diagnosis. Complaints of pain, increase in size or bleeding from a mass post operatively that is cyclically associated with menstrual cycle is almost pathognomonic. Surgical excision remains the treatment of choice. We report three cases treated in our institute.

Keywords: Caesarean section, Endometriosis, Scar

\section{INTRODUCTION}

Endometriosis is an ectopic implantation of functioning endometrial tissue outside the uterus, the commonest site being pelvis. Extra pelvic endometriosis is seen in abdominal wall, bowel, peritoneum, omentum and umbilicus. ${ }^{1}$ The prevalence of abdominal wall scar endometriosis following gynaecological and obstetrical surgeries was found to be $1.6 \% .^{2}$ It is easily confused with stitch granulomas, abscess, haematoma and keloids. The three cases that we are reporting are in parous women following caesarean sections.

\section{CASE REPORT}

\section{Case 1}

A 26-year-old woman presented with complaints of pain, swelling and bleeding from a small mass on the infraumbilical midline vertical caesarean section scar. She had undergone previous two caesarean sections, the first one three years back and the second one eight months back. The pain increased during menses with mild bleeding from the scar on the first day since past three months. Findings on ultrasonography were nonspecific; the mass was above the rectus sheath. A diagnosis of scar endometriosis was formed. On surgical exploration, a cystic mass of $1.2 \mathrm{~cm} \mathrm{X} 2 \mathrm{~cm}$ was removed. Microscopically the mass was shown to have endometrial origin with endometrial glands with stroma in Figure 1.

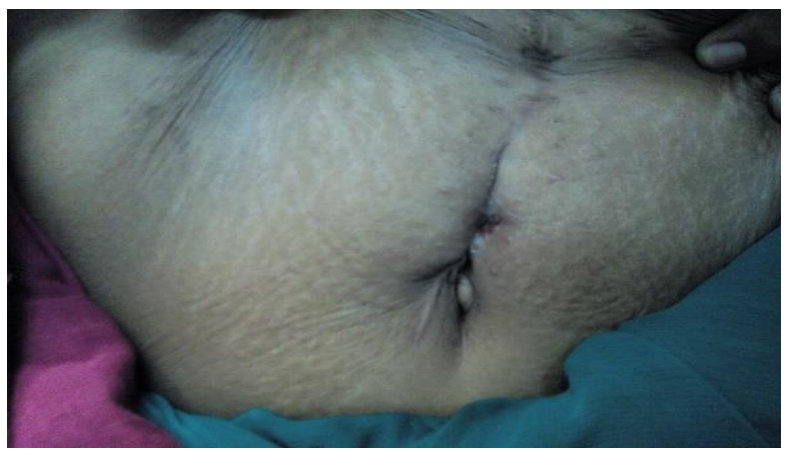

Figure 1: External opening of endometriotic sinus tract on previous ceaserean scar.

Case 2

A 22 year old woman presented with a reddish, tender mass of $2.5 \mathrm{~cm} \times 2.5 \mathrm{~cm}$ at the right angle of Pfannensteil 
scar of caesarean section done three years back. The pain increased during menses. In this case the ultrasound findings were suggestive of hypoechoic solid mass above the rectus sheath. Scar endometriosis was suspected in this case. Wide local excision with $1 \mathrm{~cm}$ margin was done. Histopathological examination revealed endometrial glands with stroma.

\section{Case 3}

A 30-year-old woman presented with complaints of serous discharge from a sinus at the left end of Pfannenstiel scar of caesarean section done fourteen months back with pain at the site. There was no history of cyclical variation. Ultrasonography reported a hypoechoic cystic mass of $2.5 \mathrm{~cm} \times 1.5 \mathrm{~cm}$ lying above the rectus sheath. The preliminary diagnosis made was that of abscess at the wound site. Surgical exploration revealed a mass with spongy consistency. On histopathological examination, endometrial glands were identified with focal areas of chronic inflammation and fibrous tissue.

\section{DISCUSSION}

Caesarean section scars are the most common site for abdominal wall endometriosis with incidence of 0.03 $0.04 \% .^{3}$ The implants are more likely to occur because of procedures where handling of endometrial tissue is involved like caesarean section, hysterectomies, ectopic pregnancies, salpingostomies. The predominant mechanism causing abdominal wall scar endometriosis is that of direct dissemination of endometrial cells into the wound at the time of surgery. The proliferative potential of well differentiated cells is limited, transfer of endometrial stem cells at the time of surgery with proliferation at the new site seems more likely. ${ }^{4}$ Endometrial cell dissemination via lymphatic or haematogenous routes can also occur. ${ }^{5}$ Women with symptomatic endometriosis present with small tender pelvic mass associated with incision site of previous surgery. Suspicion of scar endometriosis is further augmented by presence of cyclical pattern with worsening during menses. Two of our cases reported this cyclical variation. Symptoms of scar endometriosis may manifest several months to many years after the surgery, ranging from six months to twenty years. ${ }^{6}$ In two of our cases, we made the preoperative diagnosis of scar endometriosis, but it was an incidental finding in the third case. This scenario is well reported in the literature. ${ }^{7}$ In a study of 82 cases, $40 \%$ symptoms were exacerbated with menses; $33 \%$ were associated with cesarean section scars; and cyclical hemorrhage into the mass was present $12 \% .^{8}$ On ultra sound, the mass appears hypo echoic and heterogeneous with internal echoes. MRI has been recommended for diagnosis of scar endometriosis due to its high spatial resolution, which helps in better definition of planes between muscles and abdominal subcutaneous tissue. Histopathology is the gold standard of diagnosis. Endometrial glands, stroma and hemosiderin pigments are seen. Wide local excision with one $\mathrm{cm}$ margin is recommended. It is diagnostic as well as therapeutic. Medical management has been found to be unsatisfactory. ${ }^{9}$ Presence of concomitant pelvic endometriosis has been found to be 14.3 to $26 \%$.

\section{CONCLUSION}

Scar endometriosis should be suspected in patients with postoperative mass or nodules at the incision site with aggravation of complaints during menses. Surgical excision remains the main stay of treatment. Good care and proper technique during caesarean section may help in preventing endometriosis.

\section{Funding: No funding sources \\ Conflict of interest: None declared \\ Ethical approval: Not required}

\section{REFERENCES}

1. Bergqvist A. Different types of extragenital endometriosis: A review. Gynaecol Endocrinol. 1993;7:207-21.

2. Gunes M, Kayikcioglu F, Ozturkoglu E, Haberal A. Incisional endometriosis after caesarean section, episiotomy and other gynaecological procedures. J Obstet Gynaecol Res. 2005;31:471-5.

3. Nominato NS, Prates LF, Lauar I, Morais J, Geber S Caesarean section greatly increases risk of scar endometriosis. Eur J Obstet Gynaecol. 2010;152:835 .

4. Suginami H. A reappraisal of the coelomic metaplasia theory by reviewing endometriosis occurring in unusual sites and instances. Am J Obstet Gynecol. 1991;165:214-8.

5. Ueki M. Histological study of endometriosis and examination of lymphatic drainage in and from the uterus. Am J Obstet Gynecol. 1991;165:201-9.

6. Blanco RG, Parithivel VS, Shah AK, Gumbs MA, Schein M, Gerst PH. Abdominal wall endometriosis Am J Surg. 2003;185(6):596-8.

7. Nirula R, Greaney GC. Incisional endometriosis: An underappreciated diagnosis in general surgery. J Am Coll Surg. 2000;190:404-407.

8. Bektas H, Bilsel Y, Sari YS. Abdominal wall endometrioma: A10-yearexperienceandbreif review of literature. J Surg Res. 2010;164:77-81.

9. Rivlin ME, Das SK, Patel RB, Meeks GR. Leuprolide acetate in the management of caesarean scar endometriosis. Obstet Gynecol. 1995;85:838839.

Cite this article as: Thakur R, Sambarey PW, Katha D. Post caesarean scar endometriosis: reporting three cases. Int J Reprod Contracept Obstet Gynecol 2017;6:1125-6. 